\title{
膨潤誘起座屈によって生じるダイアモンドプレートパターンの有限要素解析
}

\section{Finite element analysis of diamond plate pattern generated by swelling-induced buckling}

$\bigcirc$ 稲垣 貴裕（名大院） 桑山 剛（名大院） 正 奥村 大（名大） 正 大野 信忠（名大）

Takahiro INAGAKI, Tsuyoshi KUWAYAMA, Dai OKUMURA, and Nobutada OHNO,

Nagoya University, Furo-cho, Chikusa-ku, Nagoya 464-8603, Japan

Key Words: Buckling, Swelling, Gels, Polymeric films, Instability, Finite element analysis

\section{1. はじめに}

高分子ゲル膜に膨潤（溶媒吸収による体積増加）誘起型の 座屈を生じさせることによって, 複雑かつ多彩な規則的パタ ーンの創製が可能であることが観察されている．例えば，円 孔を有する高分子ゲル膜には, 膨潤によってダイアモンドプ レートパターンと呼ばれる特徵的な座屈パターンが現れる だけでなく, 予負荷によって座屈パターンは変化する ${ }^{(1)}$. し たがって，このような現象の機構を解明するために，膨潤を 考慮した固体力学的数值シミュレーションの必要性は非常 に高いといえる.

膨潤は応力状態に依存して進展する現象であり, Hong ら ${ }^{(2)}$ は, 応力及び化学ポテンシャルのつり合いを考慮した解析を 行うために, Flory-Rehner の自由エネルギーに対して, 有限 要素解析ソフトへの実装方法を示した。この研究では, 主に 実装方法の検証が行われており, 適用性を示すために円孔を 有するゲル膜の膨潤座屈問題が解析された。しかしながら, 解析条件の詳細についてはほとんど述べられていない. また, 実物の円孔ゲル膜 ${ }^{(1)}$ は初期不整を必ず含むことから，膨潤座 屈挙動に対する初期不整の影響を調べることは重要である.

そこで本研究では, Hong らの不均質場理論 ${ }^{(2)}$ 用いて, 円 孔を有する高分子ゲル膜に生じるダイアモンドプレートパ ターンの有限要素解析を行う. 解析では簡単のため, 一般化 平面ひずみ問題を考える。 また, 周期単位には $10 \times 10$ の土 ニットセル (図 1 参照) を考え, 周期単位中に含まれる円孔 の形状にランダムな初期不整を与え, パターン形成に初期不 整の果たす役割について考察する。

\section{2. 不均質場理論}

Flory-Rehner の自由エネルギーWは，高分子の弾性エネル ギー項とゲル材料を構成する高分子と溶媒分子の混合エネ ルギー項の和として，

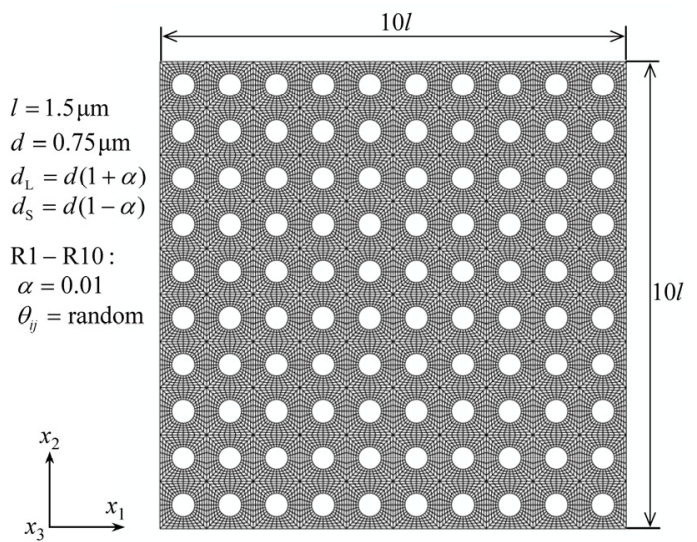

Fig. 1 Initial configuration and finite element meshes for Random models R1-R10 (10x10 unit cells).

$$
\begin{aligned}
W= & \frac{1}{2} N k T(I-3-2 \log J) \\
& -\frac{k T}{v}[v C \log (1+1 / v C)+\chi /(1+v C)]
\end{aligned}
$$

と表される.ここで, $N, k, T$ はそれぞれ乾燥状態における単 位体積当りの高分子鎖数, ボルツマン定数, 絶対温度を表し, $v, C, \chi$ はそれぞれ溶媒 1 分子当りの体積, ゲル材料中での 溶媒分子の濃度, 高分子と溶媒の相互作用を表す無次元パラ メータを表す. また, 変形勾配を $F_{i j}(=\mathbf{F})$ と表すとき $I=F_{i j} F_{i j}$, $J=\operatorname{det} \mathbf{F}$ である.

Hong $ら^{(2)}$ は, 式(1)にルジャンドル変換 $(\hat{W}=W-\mu C)$ を 行い, ゲル材料の体積変化を表す $J$ とゲル材料中の溶媒分子 の濃度を表す $C$ を結び付ける関係式 $(1+v C=J)$ を用いて, 自由エネルギーの変換形式

$$
\begin{aligned}
\hat{W}(\mathbf{F}, \mu)= & \frac{1}{2} N k T(I-3-2 \log J) \\
& -\frac{k T}{v}\left[(J-1) \log \frac{J}{J-1}+\frac{\chi}{J}\right]-\frac{\mu}{v}(J-1)
\end{aligned}
$$

を導いた. ここで， $\mu$ はゲル材料中の溶媒分子の化学ポテン シャルであり, つり合い状態では, 外部の溶媒分子の化学ポ テンシャル $\hat{\mu}$ と等しい值となる. $\hat{\mu}$ の值は乾燥状態において $\hat{\mu}=-\infty$ あり, 值を増加させるにしたがって, 高分子中には 溶媒が浸透していき, ゲル材料の膨潤は進行する.

式(2)の自由エネルギー $\hat{W}$ は，化学ポテンシャルを温度な どの変数で置き換えれば, 有限要素解析ソフトにおいて, 超 弾性体用のユーザーサブルーチンに実装することが可能で ある.したがって, 本研究では, 有限要素解析ソフト Abaqus に, Hong $ら^{(2)}$ の作成したユーザーサブルーチンUHYPER を 組込んで解析を実施する。 なお, 乾燥状態では $\hat{\mu}=-\infty$ とな り，初期值を設定できない. Hong らは，この問題を避ける ために, 初期状態として自由膨潤によって体積変化している 状態 $\left(\mathbf{F}_{0}=\lambda_{0} \delta_{i j}\right)$ を考えた. 本研究でもこの方法を採用するこ ととし， $\lambda_{0}=1.01$ とする. 詳細については文献 ${ }^{(2)}$ に詳しく述 ベられている.

\section{3. 解析モデル}

解析に用いる周期単位を図 1 に示す. 寸べての円孔は長径 を $d_{\mathrm{L}}=d(1+\alpha)$, 短径を $d_{\mathrm{S}}=d(1-\alpha)$ とするだ円であり, $d=$ $1.5 \mu \mathrm{m}, \alpha=0.01$ とする. また, それぞれの円孔に対して, 水平方向と長径方向の間の角度 $\theta_{i j}(i=1,2, . ., 10, j=1,2, . ., 10)$ を ランダムに与える.ランダムさの影響を考慮するため, 10 パターンのランダムモデル R1-R10をそれぞれ解析する.

実験 ${ }^{(1)}$ に対応する境界条件を再現するため，周期単位境界 上には周期境界条件を与え, 面内の巨視的ひずみ成分を零に 拘束する $\left(\bar{H}_{11}=\bar{H}_{22}=\bar{H}_{12}=0\right)$. また, 要素分割には一般化平 面ひずみ要素(CPEG8RH)を用い, 化学ポテンシャルを初期值 $(\hat{\mu}<0)$ から順次増加させることによって溶媒の吸収プロセ スを表すことにする。したがって, 溶媒の吸収にともない, 


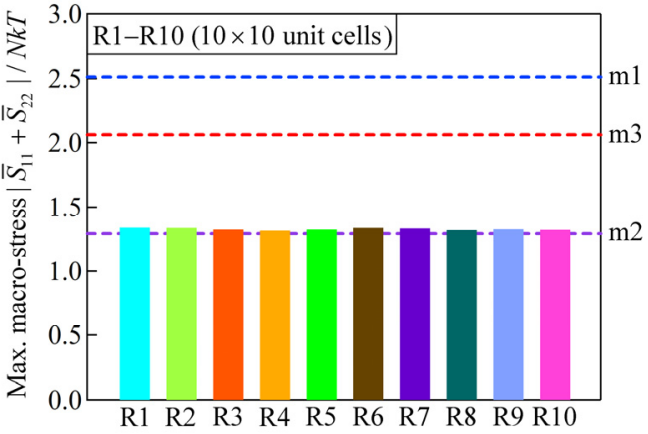

Fig. 2 Maximum macroscopic stresses for Random models R1-R10 (10x10 unit cells).

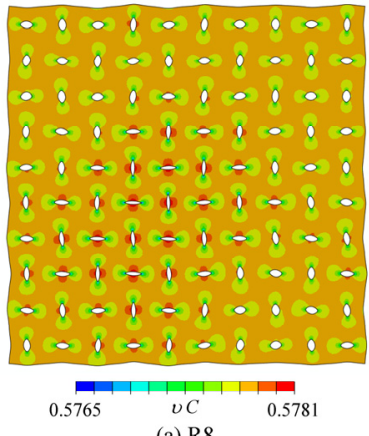

(a) $\mathrm{R} 8$

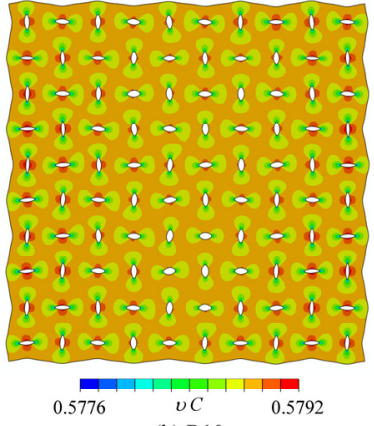

(b) R10
Fig. 3 Deformed configurations (displacement 2x) and normalized concentration distributions $v C$ at unstable point; Random models (a) R8 and (b) R10 (10x10 unit cells).

巨視的ひずみの面外成分 $\bar{H}_{33}(\geq 0)$ 及び巨視的応力の面内成 分 $\bar{S}_{11}, \bar{S}_{22}(\leq 0)$ がそれぞれ生じる.

本研究では, 解析結果の定性的な検討を主目的とし, $N k T$ については応力を無次元化するために用い, $N v=10^{-3}, \chi=$ 0.1 とした. どちらの值も溶媒分子にとって標準的な值であ る(2).さらに, 座屈パターンの進展を定量化するために, 個々 の円孔に対して, 正円からのずれを表すスカラー值 $\Delta$ を次の ように定義する。

$$
\Delta=\min _{\mathbf{x}_{0} \in \mathbf{x}}\left(r_{\text {max }}\left(\mathbf{x}_{0}\right)-r_{\text {min }}\left(\mathbf{x}_{0}\right)\right)
$$

ここで， $r_{\max }$ と $r_{\min }$ は着目する円孔の外接円及び内接円の半 径を表し, 点 $\mathbf{x}_{0}$ は $r_{\max }-r_{\min }$ を最小化する円の中心である. 周 期単位中のすべての円孔に対する平均值を $\bar{\Delta}$ と表すとき, 座 屈前までは $\bar{\Delta} \approx 0$ であり, 座屈が始まると $\bar{\Delta}>0$ となる.

\section{4. 解析結果}

図 2 には，ランダムモデル R1-R10 に対して，座屈によっ てパターン化が始まるときの最大応力值をそれぞれ示して おり，破線 m1-m3 は試験計算として $2 \times 2$ 周期単位で得られ た結果である. モデル $\mathrm{m} 2$ の最大応力值はダイアモンドプレ ートパターンが生じる志力值に対応しており, この図からわ かるように，ランダムモデル R1-R10の值はこの值とほとん ど同じであることがわかる，このことは，すべてのランダム モデル R1-R10 がダイアモンドプレートパターンへの変態を 予測していることを示唆する. 図 3 は，ランダムモデル R8 と R10 の変形状態及び溶媒分子の濃度分布（無次元量）を示 しており，ダイアモンドプレートパターンでの全体的な座屈 の発生を確認することができる.そのほかのランダムパター ンについても同様の結果であった。 寸なわち, ランダムな初 期不整は，ダイアモンドプレートパターンの発生を助ける役 割を果たしていると考えられる.

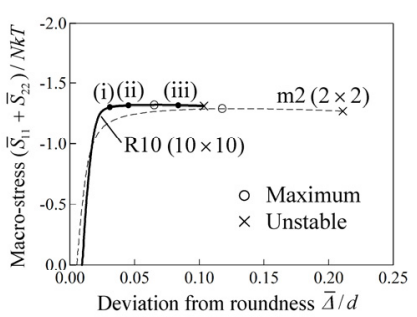

(a) Response of Random model R10

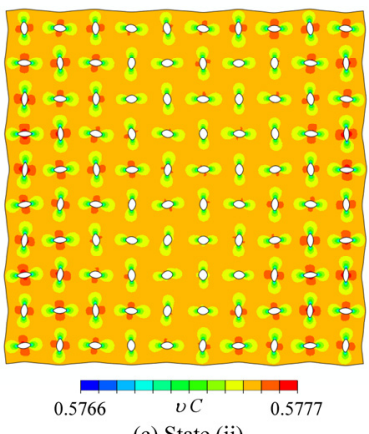

(c) State (ii)

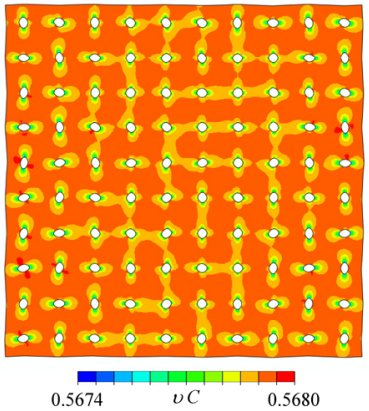

(b) State (i)

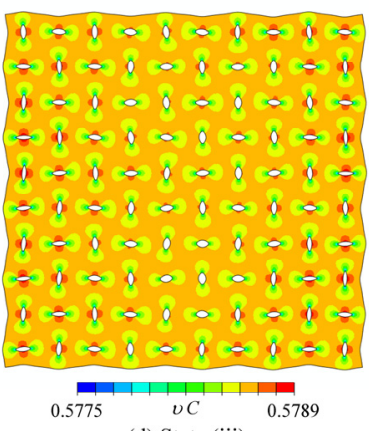

(d) State (iii)
Fig. 4 Deformation process finalizing the homogeneous transformation into the diamond plate pattern for Random models R10 (10x10 unit cells); (a) macroscopic stress as a function of the average deviation from roundness, and (b), (c) and (d) deformed configurations (displacement 2x) and normalized concentration distributions $v C$ for states (i), (ii) and (iii), respectively.

このことを確かめるため, ランダムモデル R10 の変形過程 を図 4 に示す.この図中の状態(i),(ii),(iii)における変形状態は 図 4(b)-(d)にそれぞれ示すとおりであり, パターン化の開始 初期段階 (状態(i)）では, 周期単位の両側面近傍において, 局所的にダイアモンドプレートパターンの発生が確認され, 状態(ii),(iii)と進むにつれて, ダイアモンドプレートパターン は周期単位の中心部にも伝ぱしていることがわかる。しかも， 図4(a)からわかるように，この伝ぱは応力レベルがほぼ一定 の值で進展する.このため, 図 3 の破線 $\mathrm{m} 1$ や $\mathrm{m} 3$ によって 予測されるより高次の座屈パターンは局所的にも発生する ことはできず, 結果として, 周期単位内にはダイアモンドプ レートパターンでの均質なパターン化が生じる.この機構は, 実験 ${ }^{(1)}$ において, ダイアモンドプレートパターンが現れる原 因を説明することができ, ランダムな初期不整がダイアモン ドプレートパターンへの均質なパターン変化に対して重要 な役割を果たしていることを示す結果である.

\section{文献}

(1) Zhang, Y., Matsumoto, E.A., Peter, A., Lin, P.C., Kamien, R.D., Yang, S., One-step nanoscale assembly of complex structures via harnessing of an elastic instability. Nano Lett. Vol.8 (2008), pp.1192-1196.

(2) Hong, W., Liu, Z., Suo, Z., Inhomogeneous swelling of a gel in equilibrium with a solvent and mechanical load. Int. J. Solids Struct. Vol.46 (2009), pp.3282-3289. 